понятий как конфликт интересов, однако, данному феномену скорее свойственна природа низкой квалификации персонала и такой человеческий фактор как лень.

Теперь стоит рассмотреть реальные примеры формирования элиты и значимость ценностно-мотивационного аспекта в данном процессе. Наиболее ярко это прослеживается в религиозной элите, например в Русской Православной Церкви. Элита выделена по признаку иерархии (духовные саны) и задаёт направление развития православного общества на территории России. Христианские религиозные ценности в данном примере и являются причиной формирования данной элиты, а поддержка верующих является следствием реализации данных ценностей и выступает мотивацией элиты - помогать людям в соответствии с Христианскими ценностями. Помимо Русской Православной Церкви есть иной достаточно интересный и уникальный пример религиозной элиты, который в тот же момент является и политико-административной элитой. Таким примером является микрогосударство Ватикан. В данном государстве основной элитарный слой является симбиозом религиозной и политико-административной элиты. Это играет важную роль в деятельности государства, которое является центром Католического Христианства во всём мире. Данные примеры являются доказательством того, что элита обязана иметь под собой ценностно-мотивационною опору, которая будет задавать направление деятельности элитарного слоя для обеспечения блага нижестоящих слоёв.

Таким образом, можно подвести итог исследования причин формирования элит и их деструктивных тенденций. Особенностью данного комплекса является его неизменность элита стремится реализовать эффективное управление для дальнейшего развития на благо всего общества, но из-за иерархических различий и нарушений коммуникации могут возникнуть кризисы непонимания, что и ведёт за собой деструктивную деятельность элит для общества. Целостность групп и здравая коммуникация являются основными задачами в реализации эффективной деятельности элит.

1. Куколев, И.В. Трансформация политических элит в России / И.В. Куколев // Общественные науки и современность. - 2016. - No 4. - С. 90-110.

\title{
Фалько М.Д. \\ Судейское усмотрение и его пределы в стадии подготовки к судебному заседанию
}

Кубанский государственный аграрный университет им. И. Т. Трубилина

doi: 10.18411/trnio-01-2022-76

(Россия, Краснодар)

\section{Аннотация}

В статье проводится анализ судейского усмотрения и его пределы в стадии подготовки к судебному заседанию, исследуются возможности принятия решений по судейскому усмотрению при разрешении вопроса о подсудности, при дополнительном ознакомлении с материалами гражданского дела, при решении вопроса о назначении предварительного слушания, при определении существенности процессуальных нарушений в случаях возращения дела истцу, при рассмотрении ходатайств об исключении доказательств в ходе предварительного слушания, при решении вопроса о приостановлении производства по гражданскому делу, прекращении гражданского дела и др. Безусловно, данная тема актуальна в современном мире.

Ключевые слова: судейское усмотрение, гражданское дело, подсудность, предварительное слушание, гражданский процесс.

\section{Abstract}

The article analyzes judicial discretion and its limits in preparation for a court session, examines the possibilities of making decisions at judicial discretion when resolving the issue of 
jurisdiction, with additional familiarization with the materials of a civil case, when deciding on the appointment of a preliminary hearing, when determining the materiality of procedural violations in cases of returning the case to the plaintiff, when considering applications for the exclusion of evidence during the preliminary hearing, when deciding on the suspension of proceedings in a civil case, termination of a civil case, etc. Of course, this topic is relevant in the modern world.

Keywords: judicial discretion, civil case, jurisdiction, preliminary hearing, civil procedure.

Одним из существенных препятствий в создании оптимальных институциональных условий для развития бизнеса в современной России выступает несовершенство существующей в нашей стране судебной системы, что негативно влияет на состояние экономической безопасности большинства хозяйствующих субъектов [1]. Всякое заинтересованное лицо вправе в соответствии со ст. 3 ГПК РФ в порядке, установленном законом, обратиться в суд за защитой нарушенного или оспариваемого права или охраняемого законом интереса [2].

На подготовительной стадии судебного разбирательства судьей решается вопрос о принятии гражданского дела к производству в соответствии с ГПК РФ [3] для рассмотрения его по существу. При выявлении каких-либо нарушений суд принимает действия по их корректировке и производит подготовку гражданского дела для организации процедуры гражданского судопроизводства. Ни одно гражданское заявление истцом с правоустанавливающими документами не может пропустить данную стадию процесса. На данной стадии судья решает вопрос о назначении даты судебного разбирательства. Глава 14 ГПК РФ «Подготовка дела к судебному разбирательству» дает право судье совершать процессуальные действия по своему усмотрению. Изучая материалы гражданского дела до назначения его к судебному разбирательству, суд производит ревизионную деятельность. Суд по своему усмотрению производит оценку гражданского дела, т.е. изучает его и в итоге производит процессуальные действия, независимо от ходатайств, находящихся в деле.

Поступившее гражданское дело исследуется судьей и решается вопрос о подсудности. Выделяют исключительную, предметную, персональную и территориальную подсудности.

ГПК РФ формирует вопросы персональной и территориальной подсудности. Подсудность определяется судом единолично и не зависит от волеизъявления истца или ответчика без их на то согласия. В случае, если принятое судом гражданское дело данному суду не подсудно, судьей решается вопрос о подсудности дела, а при решении данного вопроса допустимо судейское усмотрение. Согласно ч. 1 ст. 29 ГПК РФ, иск к ответчику, место жительства которого неизвестно или в случае, если ответчик не имеет места жительства на территории Российской Федерации, иск может быть предъявлен в суд по месту расположения его имущества или по его последнему известному месту жительства на территории Российской Федерации.

Дополнительное ознакомление сторон с материалами гражданского дела происходит по усмотрению суда по просьбе одной из сторон согласно ст. 34 ГПК РФ, в то же время это не является судейской обязанностью. Сроки для дополнительного ознакомления с материалами дела в гражданско-процессуальном законе не установлены. Можно сделать вывод о том, что суд по своему усмотрению устанавливает необходимость ознакомления и срок.

Оценивая материалы гражданского дела для его рассмотрения, судья выясняет, были ли предприняты все меры по обеспечению иска, их правомерность, целесообразность и возможные причины. Данное действие производится судьей формально, поскольку законодатель исключает возможность по инициативе суда производить таковые действия [4].

Ст. 152 ГПК РФ установлены основания для проведения предварительного судебного заседания. Но специальные сроки для его проведения не установлены.

На стадии обеспечения гражданского иска в стадии подготовки к назначению судебного заседания суд рассматривает еще один вопрос о возврате искового заявления истцу. Поэтому, в соответствии со ст. 135 ГПК РФ судья по своему усмотрению или 
ходатайству стороны возвращает гражданское дело истцу для устранения препятствий его рассмотрения судом.

В случае, если суд выносит определение о возврате гражданского иска истцу, в нем должны отсутствовать пояснения в пользу истца или ответчика, поскольку это нарушает принцип состязательности и равноправия сторон.

Согласно разъяснениям Конституционного Суда РФ, основанием для возврата искового заявления истцу является нарушение гражданско-процессуального закона, в результате чего судом невозможно постановить справедливое решение [5]. При этом, суд по своему усмотрению определяет, что именно является существенным нарушением закона. В данном случае судейское усмотрение ограничено следующими пределами: если устранение нарушений невозможно судьей в судебном заседании, а возвращение дела истцу не связано с необходимостью восполнения неполноты искового заявления.

Даже если в гражданско-процессуальном законе нет прямого указания на нарушения, суд по своему усмотрению может вернуть исковое заявление. А пределы судебного усмотрения предусмотрены постановлениями Пленума Верховного Суда РФ и правовыми позициями Конституционного Суда РФ, на основании чего судебная практика является законной и обоснованной.

Многие правоведы высказываются о том, что необходимо ограничить инициативу суда о возвращении искового заявления истцу, поскольку суд по своему усмотрению тем самым назначает выгод получателя, заранее вынося свое «решение» в пользу ответчика [6]. Мы полагаем, что данное заявление подлежит одобрению, а в идеале внесено с изменениями в ГПК РФ.

На предварительном судебном заседании может решаться вопрос по ходатайству одной из сторон об объединении нескольких гражданских дел воедино по основаниям, которые прямо не предусмотрены законом. Приведем пример: столкновение двух автомобилей в результате нарушения правил дорожного движения, в результате чего стороны, защищая свои права и интересы обращаются в суд за возмещением материального ущерба, или нанесение в драке обеим сторонам материального вреда, в судебном заседании рассматривается его возмещение. Указанные основания находят свое отражение в ст. 151 ГПК РФ. Но стоит отметить, что аналогия закона, в данном случае, является вынужденной мерой.

Ссылаясь на ст. 135 ГПК РФ, суд вправе по своему усмотрению возвратить исковое заявление истцу для объединения гражданских дел в предварительном судебном заседании.

На всех стадиях судебного процесса судейское усмотрение можно рассматривать при решении вопроса об исключении, допустимости материалов, приобщаемых к гражданскому делу. При поступлении ходатайства со стороны ответчика о недопустимости доказательств, имеющихся в материалах гражданского дела, предъявленных истцом, судья исследует достоверность данных материалов, путем опроса лиц, располагающими сведениями относительно заявленных документов, при этом соблюдая все нормы ГПК РФ.

Так, в соответствии со статьями 35, 67 и 71 ГПК РФ суд по своему усмотрению или ходатайству одной из сторон вправе признать доказательства недопустимыми. Как следствие, назначить предварительное судебное заседание, а затем разрешить заявленное ходатайство о принятии доказательства недопустимым. Однако, в указанных статьях не обозначен порядок признания доказательств недопустимыми по усмотрению судьи.

Пользуясь внутренним убеждением, судья оценивает доказательства, представленные сторонами на стадии предварительного заседания. В случае, если стороной оппонента заявляется ходатайство о недопустимом доказательстве и подтверждается документально, а также позицией одной из сторон, суд вправе исключить заявленное доказательство из рассматриваемого гражданского дела. Иногда стороны заявляют о подобном ходатайстве, указывая на незначительные нарушения гражданско-процессуального закона, в таком случае суд по своему усмотрению решает удовлетворить ли таковое требование или нет. Ч. 2 ст. 55 ГПК РФ четко указывает на то, что доказательства, полученные с нарушениями требований 
ГПК РФ по делу, оказываются недопустимыми. Судебная практика только подтверждает вышесказанное. Можно ясно утверждать, что доказательства оказываются недопустимыми при существенном нарушении гражданско-процессуального закона. Ученые писали, что даже при малейших нарушениях гражданско-процессуального закона, доказательства стоит расценивать допустимыми.

Подытоживая, отметим, что ГПК РФ заключает в себе пределы судейского усмотрения. Справедливость, целесообразность и разумность - главные критерии принятия судом решения по своему усмотрению. Можно заключить, что под существенными при признании доказательств недопустимыми следует понимать нарушения гражданскопроцессуального закона, которые повлекли нарушение гарантированных Конституцией Российской Федерации прав человека и гражданина или существенно нарушили установленный гражданско-процессуальным законом порядок их сбора и закрепления, что могло исказить содержание доказательства и повлиять на его достоверность, а так же если сбор и закрепление доказательств реализовано ненадлежащим лицом или органом либо в результате действий, не предусмотренных процессуальными нормами. В результате чего, хотелось бы дополнить ст. 67 ГПК РФ п. 8 и отразить в ней возможность судьи оценивать значимость нарушений гражданско-процессуального закона при определении доказательства допустимым или недопустимым.

$$
* * *
$$

1. Петров, И. В. К вопросу об электрон-ном правосудии в арбитражном и гражданском судо-производстве / И. В. Пет-ров, И. И. Дементеева // The Mechanism of Economic and Legal National Security: Experience, Problems and Prospects : Materials of scientific-practical conference. - Лондон : LSP, 2016. - C. 172-180.

2. Адвокатура в России. Власов А.А., Газетдинов Н.И., Исаенкова О.В., Щербачева Л.В., Эриашвили Н.Д., Казанцев С.Я., Карцхия А.А., Дементеева И.И., Колоколов Н.А., Кирсанов А.Ю., Миронов А.Л., Алексий А.П. учебное посо-бие для студентов высших учебных заведений, обучающихся по специальности 030501 "Юриспруденция" : учебное пособие для курсантов и слушателей образовательных учреждений МВД России юридического профиля / Москва, 2008.

3. Гражданский процессуальный кодекс Российской Федерации от 14.11.2002 № 138-Ф3 (последняя редакция) // Собрание законодательства РФ. - 18.11.2002. - № 46. - ст. 4532.

4. Крашенников Е. А. Гражданское право и процесс. Избранные труды. М.: Юрайт, 2020. 1125 с.

5. Определение Конституционного Суда РФ от 4 июля 2017 г. № 1442-О “Об отказе в принятии к рассмотрению жалобы гражданина Александрова Владимира Юрьевича на нарушение его конституционных прав частью четвертой статьи 61 Гражданского процессуального кодекса Российской Федерации" // [Электронный ресурс] https://www.garant.ru/products/ipo/prime/doc/71622868/.

6. Лебедев М. Ю., Барсукова В. Н., Шаяхметова М. Н. Гражданский процесс. Учебник и практикум для вузов. М.: Юрайт, 2019. 446 с. 